\title{
MUZEUM JANA PAWLA II W STALOWEJ WOLI - KOŚCIELNA PLACÓWKA MUZEALNA PRZY PARAFII PW. MATKI BOŻEJ KRÓLOWEJ POLSKI
}

Chociaż Muzeum Jana Pawła II w Stalowej Woli zostało powołane do istnienia 4 listopada 2009 r. dekretem biskupa sandomierskiego Krzysztofa Nitkiewicza $^{1}$, zaś otwarte i poświęcone 16 października 2010 r., w rocznicę wyboru papieża Polaka na Stolicę Piotrową ${ }^{2}$, ostateczny kształt uzyskało dopiero 11 grudnia 2016 r., poprzez urządzenie w kolejnych salach muzealnych stałej ekspozycji A jutro jest nieznane. Podziemna Solidarność w Stalowej Woli 1982-1989. Zasadniczym celem działalności Muzeum jest bowiem:

[...] gromadzenie, przechowywanie, opracowywanie, eksponowanie i udostępnianie dziedzictwa kulturowego i duchowego związanego z osobą św. Jana Pawła II, historią parafii, miasta, regionu oraz działalnością niepodległościową i społeczną Niezależnego Samorządowego Związku Zawodowego „Solidarność"’.

W pierwszym etapie tworzenia Muzeum przypomniano papieskie nauczanie. $\mathrm{Na}$ tle wielkoformatowych fotografii i cytatów z papieskich wystąpień zaprezentowane zostały pamiątki związane ze św. Janem Pawłem II. Ukazane też zostały związki papieża ze Stalową Wolą ${ }^{4}$ Drugi etap tworzenia Muzeum został zrealizowany w ramach projektu Patriotyzm Jutra. Wystawa odwołuje się do historii „Solidarności”, która jest ważnym elementem polskiego dziedzictwa narodowego, przypomina sylwetki twórców oraz okoliczności strajków sierpniowych $1988 \mathrm{r}$. w Stalowej Woli.

Lokalizacja Muzeum przy stalowowolskim kościele Matki Bożej Królowej Polski jest nieprzypadkowa. Nawiązuje do więzi Jana Pawła II ze Stalową Wolą

${ }^{1}$ Dekret w sprawie budowy muzeum Jana Pawła II w Stalowej Woli - 4 listopada 2009, „Kronika Diecezji Sandomierskiej” (dalej: KDS), 102 (2009) nr 11-12, s. 682.

${ }^{2}$ A. Trześniowska, Muzeum Jana Pawła II, „Niedziela Sandomierska”, 44 (2010) s. II.

${ }^{3}$ Statut Muzeum Jana Pawta II w Stalowej Woli, rozdz. 2, § 4, pkt 1, http://bazylikastw.pl/muzeum-jana-pawla-ii/akty-prawne/ (dostęp: 31.12.2016).

${ }^{4}$ A. Rusak, L. Mizera, Muzeum Jana Pawła II w Stalowej Woli [folder informacyjny]. 
sięgające czasów, gdy jako arcybiskup krakowski poświęcił w 1973 r. kościół stalowowolski ${ }^{5}$ oraz do historii działań „Solidarności”, gdy w latach 80. XX wieku w obiektach parafialnych gromadzili się stalowowolscy opozycjoniści, tam też koncentrowało się niezależne życie kulturalne ${ }^{6}$. Nie można też pominąć roli Jana Pawła II jako inspiratora przemian w Polsce, znaczenie jego pielgrzymki do Polski w czerwcu 1979 r. w kontekście powstania zaledwie w rok później wielomilionowej „Solidarności”’

\section{Siedziba stalowowolskiego Muzeum}

Muzeum Jana Pawła II w Stalowej Woli mieści się na parterze Domu Katechetycznego przy bazylice konkatedralnej. Tablica pamiątkowa wmurowana przy wejściu do budynków informuje:

Dom Katechetyczny jako votum dziękczynne Bogu za Kongres Eucharystyczny, trzy pielgrzymki papieża Jana Pawła II do Polski, 50-lecie Stalowej Woli.

Oddany do użytku w Uroczystość Chrystusa Króla 1987 r.

Budynek został wybudowany w latach 80 . XX w. i połączony jest przejściem podziemnym z kościołem parafialnym, używanym w celach konspiracyjnych, m.in. do ewakuacji opozycjonistów z budynku okrążonego przez Służbę Bezpieczeństwa. Już od 1983 r. w budynkach przykościelnych spotykali się działacze stalowowolskiej podziemnej Solidarności, przedstawiciele Duszpasterstwa Ludzi Pracy oraz młodzież. Dom Parafialny, a od 1987 r. Dom Katechetyczny był miejscem działalności Duszpasterskiego Ośrodka Kultury Chrześcijańskiej. Na spotkaniach podejmowano inicjatywy na rzecz kultury niezależnej, zapadały też decyzje dotyczące podziemnej Solidarności ${ }^{8}$.

Historia tego miejsca w naturalny sposób stanowi więc kontekst i dopowiedzenie wystawy muzealnej. Ekspozycja przedstawia bowiem trudne czasy budowy kościoła pw. Matki Bożej Królowej Polski w Stalowej Woli, poświęconego przez kard. Karola Wojtyłę i podniesionego przez Jana Pawła II do godności Bazyliki Mniejszej w 1998 r. Na wystawie pokazano przedmioty używane przez Jana Pawła II oraz upamiętniające Jego pontyfikat. Opracowano i wyeksponowano także historię działalności stalowowolskiej podziemnej Solidarności w latach 1982-89.

\section{Uklad ekspozycji}

Zbiory eksponowane są w siedmiu salach wystawowych połączonych wąskimi korytarzami, dostępna jest również sala kinowa. Pierwszy dział ekspozycji

${ }^{5}$ R. Niwierski, Kryptonim , Kościót”. Dzieje budowy kościoła pw. Matki Bożej Królowej Polski $w$ Stalowej Woli w dokumentach Stużby Bezpieczeństwa, Stalowa Wola 2011, s. 112-113.

${ }^{6}$ Solidarność z Kościolem. Stalowa Wola 1980-1991, red. E. Kuberna, Sandomierz 2003, passim.

${ }^{7}$ Z. Stawrowski, Solidarność znaczy więź: w kręgu myśli Józefa Tischnera i Jana Pawła II, Kraków 2010, s. 120-152.

${ }^{8}$ E. Kuberna, Wolna Polska w Kościele. Kalendarium Duszpasterskiego Ośrodka Kultury Chrześcijańskiej Parafii Matki Bożej Królowej Polski w Stalowej Woli 1983-1991, w: Solidarność z Kościolem, s. 59. 
(korytarz) ukazuje związki Jana Pawła II ze Stalową Wolą datujące się od czasu, gdy jako arcybiskup krakowski poświęcił w 1973 r. zbudowany po wielu latach trudów kościół w Stalowej Woli. Do tego faktu wracał wspomnieniami podczas pielgrzymek do Polski, gdy gościł w diecezji przemyskiej, a potem sandomierskiej, jak również przy spotkaniach z pielgrzymami ze Stalowej Woli w Watykanie. Jan Paweł II w homilii podczas mszy św. sprawowanej w Sandomierzu w 1999 r. powiedział:

Ze czcią nawiedzam Sandomierz - prastary Sandomierz. Ogarniam sercem inne miasta i ośrodki przemysłowe, zwłaszcza Stalową Wolę - miasto - symbol wielkiej pracy, wielkiej wiary ludzi pracy, którzy z godną podziwu ofiarnością i odwagą wznosili swoją świątynię, pomimo trudności i gróźb ze strony ówczesnych władz. Miałem radość poświęcić ten kościół’.

Kolejnym etapem kontaktów Jana Pawła II ze Stalową Wolą stał się nadany 31 sierpnia 1998 r. dekret o podniesieniu do godności bazyliki mniejszej tej samej stalowowolskiej świątyni (dokument eksponowany jest w sali wystawowej), a następnie nadanie Ojcu Swiętemu tytułu honorowego obywatela Stalowej Woli, dnia 30 grudnia 2003 r. (w zbiorach muzealnych znajduje się róża wykonana ze srebra i krzemienia pasiastego przez Cezarego Łutowicza z Sandomierza, upamiętniająca nadanie Ojcu Świętemu tytułu Honorowego Obywatela Miasta Stalowa Wola).

Wybrane papieskie przesłania jako duchowy testament kontynuowane są w pierwszej sali wystawowej, ujęte w swego rodzaju lekcje tematyczne: człowiek, ojczyzna, Kościół, rodzina, młodzież, miłość, przebaczenie, pokój, wolność, radość, dialog. Na tle fotografii i cytatów papieskich zaprezentowane zostały pamiątki osobiste po św. Janie Pawle II, tj. biała sutanna z pelerynką, piuska, naczynia liturgiczne i bielizna ołtarzowa, a także talerz i widelec, których używał podczas obiadu, gdy gościł w Sandomierzu podczas pielgrzymki do ojczyzny w 1999 r. W drugiej sali wystawowej prezentowany jest unikatowy i pełny komplet obrazków (tzw. Santini) związanych ze Świętami Bożego Narodzenia i Zmartwychwstania Pańskiego, wydawanych przez Topografia Poliglotta Vaticana przez 26 lat pontyfikatu św. Jana Pawła II ${ }^{10}$.

Kolekcja numizmatów upamiętniających ważne wydarzenia z dziejów pontyfikatu papieża Polaka została wyeksponowana w trzeciej sali. Monety, medale i plakietki przenoszą zwiedzających do czasów dawnych, przypominają pielgrzymki papieskie, jubileusze Kościoła, rocznice religijne, pozostając w relacji do papieskiego nauczania ${ }^{11}$.

Sala kinowa to łącznik między wystawą papieską, a ekspozycją poświęconą działalności stalowowolskiej podziemnej „Solidarności”, gdzie wyświetlane są dwa pięciominutowe filmy: Papież wolności i Solidarność podziemna. W zbio-

${ }^{9}$ Te papieskie słowa zostały umieszczone na postumencie pomnika Jana Pawła II, ustawionego w 2002 r. przed frontonem kościoła.

${ }^{10}$ Kolekcja obrazków prezentowana była wcześniej na wystawach czasowych, opublikowana w książce pod red. ks. Jacka Uliasza: Oblicze Boga w tajemnicach Bożego Narodzenia i Zmartwychwstania Pańskiego, Rzeszów 2003.

${ }^{11}$ S. Gurba, Święty Jan Pawet II widziany poprzez pamiatki kolekcjonerskie - Muzeum Jana Pawta II w Stalowej Woli, KDS, 108 (2015) z. 9-10, s. 594-602. 
rach znajdują się także inne filmy krótkometrażowe, m.in. reportaż pt. Solidarność - nie żaluję, przygotowany przez uczennice Samorządowego Liceum Ogólnokształcącego w Stalowej Woli, który zwyciężył w konkursie Solidarność oczami młodych zorganizowanym w ramach projektu A jutro jest nieznane.

Kolejna sala wystawiennicza to Narzędziownia - początek. Przypomina ona czas powstania i legalnej działalności NSZZ Solidarność w Stalowej Woli, która najpierw zawiązała się w Hucie Stalowa Wola na wydziale M-01, czyli Narzędziowni. Klimat hali fabrycznej oddaje stół warsztatowy, lampy oświetleniowe, zegar i karty zegarowe do rejestracji czasu pracy. W sali tej znajdują się biuletyny oraz prasa solidarnościowa - zarówno eksponaty muzealne oraz kopie przygotowane dla zwiedzających ${ }^{12}$.

Mieszkanie opozycjonisty zrekonstruowane w kolejnej sali to miejsce, gdzie toczyły się Polaków rozmowy o tym, co można i trzeba robić, aby godnie żyć w czasach rządów komunistycznych. Mieszkanie nie było wtedy bynajmniej bezpiecznym azylem. Bywało podziemną drukarnią, punktem kolportażu wolnych publikacji, miejscem zebrań opozycjonistów. Bywało terenem rewizji, aresztowania domowników. Oprócz aranżacji wnętrza (umeblowanie, książki dostępne w latach 80. XX w., portret papieża na ścianie) w sali umieszczono powielacz, ukryty za kotarą, a w słuchawce telefonu słychać komunikat: rozmowa kontrolowana, przypominający o ocenzurowaniu rozmów telefonicznych po wprowadzeniu stanu wojennego w Polsce.

W następnej sali zrekonstruowano celę więzienną, która przypomina o cenie, jaką zapłaciło wiele kobiet i mężczyzn za działalność opozycyjną wobec reżimu komunistycznego. Na ścianach wypisano listę represjonowanych opozycjonistów ze Stalowej Woli i okolic. W gablocie natomiast umieszczono bezcenne pamiątki, wykonane przez stalowowolskich opozycjonistów w więzieniach: różaniec z chleba, drewniany krzyż, koszula więzienna z wyszytymi napisami: Solidarność, Załęże 13.12.81 - 5.06.82.

Korytarz prowadzący do kolejnej sali to symbol trudnej drogi ku wolności. $\mathrm{Na}$ ścianach wyeksponowano m.in. dokumenty represji, a także znaczki drukowane i kolportowane w Stalowej Woli oraz odciski stempli wykonywanych w ośrodkach odosobnienia. Korytarz prowadzi do niewielkiej, ale bardzo istotnej wystawy. Duszpasterski Ośrodek Kultury Chrześcijańskiej - pod taką nazwą kryło się centrum dowodzenia konspiracyjną pracą niepodległościową w Stalowej Woli ${ }^{13}$. Na ekranie dotykowym prezentowane są filmy, które opowiadają historię tamtych lat. Ostatnia sala Strajki 1988 to przełomowe wydarzenie w dziejach stalowowolskiej opozycji. Szczególne znaczenie miał strajk podjęty 22 sierpnia $1988 \mathrm{r}$. w Hucie Stalowa Wola ${ }^{14}$. Jego etapy ilustrują plansze rozmieszczone w tej sali, a atmosferę tamtych dni możemy poznać z filmów dokumentacyjnych. Na ścianie

${ }^{12}$ Opis koncepcji wystawy o podziemnej Solidarności został opracowany npdst. ustnej relacji Anny Garbacz, autorki scenariusza wystawy z dnia otwarcia ekspozycji, tj. 11 grudnia 2016 r.

${ }^{13}$ M. Krzysztofiński, Parafia Matki Bożej Królowej Polski w Stalowej Woli-oaza kultury niezależnej, w: Kościót i kultura niezależna, red. B. Tracz, Katowice 2011, s. 148-159.

${ }^{14}$ M. Bukała, Robotnicy, duchowni i aparat administracyjno-partyjny. Strajki w Hucie Stalowa Wola w 1988 roku, „Roczniki Teologiczne”, 57 (2015) z. 4, s. 219-233. 
natomiast powstała niezwykła „dokumentacja” - odciski rąk uczestników strajku, którzy byli obecni na wernisażu wystawy, 11 grudnia 2016 roku.

Z ostatniej sali wychodzi się ku wolności. Na ścianie korytarza, w której opowiedziano historię budowy kościoła umieszczono portret ks. abpa Ignacego Tokarczuka z odznaczeniem Orderem Orła Białego wraz z listem napisanym 15 lipca 2006 r. do ks. bpa Edwarda Frankowskiego, w czasach komunizmu „nielegalnego" proboszcza kościoła pw. Matki Bożej Królowej Polski w Stalowej Woli ${ }^{15}$. List nawiązuje do wydarzeń stalowowolskich z lat 1982-1989:

w dowód uznania i wdzięczności przekazuję portret odznaczony Orderem Orła Białego, wspólnie wypracowany naszą służbą Bogu, Kościołowi i Polsce w czasach niesłychanie trudnych.

\section{Perspektywy funkcjonowania Muzeum}

Ks. Edward Madej, proboszcz parafii konkatedralnej, prałat Kapituły Konkatedralnej w Stalowej Woli, w dniu otwarcia Muzeum powiedział:

Powstałe muzeum będzie miejscem ewangelizacji, zwłaszcza młodego pokolenia. Jan Paweł II może być wspaniałym przewodnikiem na drodze wszystkich ludzi ${ }^{16}$.

Dziś Muzeum jest niewątpliwie miejscem poznania postaci św. Jana Pawła II oraz historii regionu lat 80 . XX w. - tak najkrócej można określić funkcję, jaką spełnia stalowowolska instytucja. W działalność Muzeum wpisuje się wiele okazji, aby z tego dorobku kulturowego Kościoła skorzystać, poprzez zwiedzanie indywidualne oraz zorganizowane wejścia grupowe. Papieskie nauczanie oraz historię działalności stalowowolskiej podziemnej „Solidarności” przybliżają także lekcje muzealne, omawiające wybrane zagadnienia przy wykorzystaniu niektórych eksponatów muzealnych ${ }^{17}$. Ponadto Muzeum realizuje swe zadania statusowe poprzez organizowanie wystaw czasowych o tematyce papieskiej i historycznej, promującej tak artystów, jak i działalność kulturową przybliżającą pontyfikat św. Jana Pawła II i dzieje regionu ${ }^{18}$.

${ }^{15}$ B. Stanaszek, ,Zdecydowany przeciwnik ustroju”. Władze PRL wobec ks. Edwarda Frankowskiego, Sandomierz 2007, passim.

${ }^{16}$ Trześniowska, Muzeum Jana Pawła II, s. II.

${ }^{17}$ M.in. lekcje muzealne we wspomnienie liturgiczne św. Jana Pawła II, w dniach 22-24 października 2015 r., cykl zajęć muzealnych „Między historia a współczesnością. Działalność podziemnej „Solidarności” w Stalowej Woli 1982-1989 prowadzonych przez działaczy podziemnej „Solidarności", w grudniu $2016 \mathrm{r}$.

${ }^{18}$ Wystawa czasowa rzeźb zakopiańskiego artysty, Stanisława Cukierka, ukazująca osobowość, duchowość Jana Pawła II oraz bliskich mu świętych: Brata Alberta Chmielowskiego, Ojca Pio, zob. Trześniowska, Muzeum Jana Pawła II, s. II. 
W 1997 r. Jan Paweł II powiedział do uczestników II Plenarnego Zebrania Papieskiej Komisji ds. Kościelnych Dóbr Kultury:

Trzeba podkreślić potrzebę powstawania i wartość muzeów kościelnych (...) kulturowych o inspiracji chrześcijańskiej po to, by dać konkretne oblicze i pamięć historyczną chrześcijaństwu ${ }^{19}$.

Przed pierwszym i dotychczas jedynym w diecezji sandomierskiej Muzeum Jana Pawła II stoją wciąż nowe zadania, aby ewangelizować społeczność lokalną, by pielęgnować spuściznę Papieża Polaka, by jednoczyć i angażować społeczności (szkoły, uniwersytety, wspólnoty), którym patronuje św. Jan Paweł II, by dać konkretne oblicze i pamięć historyczną życiu i działalności Karola Wojtyły - św. Jana Pawła II.

${ }^{19}$ Jan Paweł II, Apel do uczestników II Plenarnego Zebrania Papieskiej Komisji ds. Kościelnych Dóbr Kultury, 25 września 1997; cytat został umieszczony na folderze informacyjnym o Muzeum. 